\title{
A case of CIDP concurrent with MGUS IgG kappa responsive to autologous stem cell transplantation
}

\author{
Giuseppe Colucci, MD, Thomas Pabst, MD, Ulrike Bacher, MD, Caterina Maggioli, MD, Chiara Zecca, MD, and \\ Claudio Gobbi, MD
}

Neurol Neuroimmunol Neuroinflamm 2020;7:e888. doi:10.1212/NXI.0000000000000888

\author{
Correspondence \\ Dr. Gobbi \\ claudio.gobbi@eoc.ch
}

Chronic inflammatory demyelinating polyradiculoneuropathy (CIDP) is an acquired immunemediated disease of the peripheral nervous system, either being isolated or associated with other systemic diseases, most frequently with lymphoproliferative subtypes. ${ }^{1} \mathrm{CIDP}$ concurrent with monoclonal gammopathy of undetermined significance (MGUS) accounts for up to $20 \%-30 \%$ of all cases, ${ }^{2}$ is often considered clinically indistinguishable from typical CIDP, and responds similarly to immunologic therapies. ${ }^{3}$ CIDP clinical course may be poorly responsive to conventional immunologic or chemotherapy treatment. ${ }^{4}$ Consequently, allogeneic and autologous hematopoietic stem cell transplantations (HSCTs) have been proposed in selected cases. ${ }^{5}$ To our knowledge, only a single patient with concurrent IgG lambda MGUS has been treated with autologous HSCT, ${ }^{6}$ and no case of IgG kappa MGUS is reported so far.

\section{Clinical case}

A previously healthy 49-year-old male patient presented with a 4-week history of progressive muscle weakness, gait ataxia, perioral paresthesias, and subjective swallowing difficulties. Neurologic examination revealed normal cranial nerves-proximal rather than distal paresis with diffusely absent reflexes and mild lower limb sensory deficiencies. CSF analysis showed increased protein $(1,185 \mathrm{mg} / \mathrm{L})$ and normal cell count. Electrophysiologic nerve conduction studies disclosed findings of demyelinating polyneuropathy (table e-1, links.lww.com/NXI/ A313); needle electromyographic examination in the arms and legs was normal. Serum VEGF concentration was also normal $(134 \mathrm{pg} / \mathrm{mL})$. Nerve ultrasound and spinal MRI showed diffuse hypertrophic, hyperechogenic nerves (figure e-1, links.lww.com/NXI/A312).

Figure 1 illustrates the clinical course and therapy schedule.

CIDP was diagnosed according to European Federation of Neurological Societies/Peripheral Nerve Society criteria, ${ }^{7}$ although a sural nerve biopsy was not deemed necessary.

Bone marrow aspirate smears and trephine biopsy demonstrated IgG kappa MGUS with 4\% kappa light chain-restricted plasma cells (table e-2, links.lww.com/NXI/A314). There was no evidence of amyloidosis or other hematologic malignancies on whole body CT scan and bone marrow biopsy. Fluorescence in-situ hybridization (FISH) revealed no cytogenetic abnormalities, and CRAB criteria (elevated calcium level, renal failure, anemia, and bone lesions) were not met.

In July 2013, walking distance was less than $20 \mathrm{~m}$ with a cane, and the patient developed respiratory distress necessitating mechanical respiratory support. High-dose chemotherapy

From the Service of Hematology (G.C., C.M.), Clinica Luganese Moncucco, Lugano; Faculty of Medicine (G.C., C.G.), University of Basel; Department of Medical Oncology (T.P.) and Department of Hematology and Central Hematology Laboratory (U.B.), Inselspital, University Hospital and University of Bern; Neurocenter of Southern Switzerland (C.Z., C.G.), Ospedale Regionale di Lugano; and Faculty of Biomedical Sciences (C.Z., C.G.), Università della Svizzera Italiana (USI), Lugano, Switzerland. 


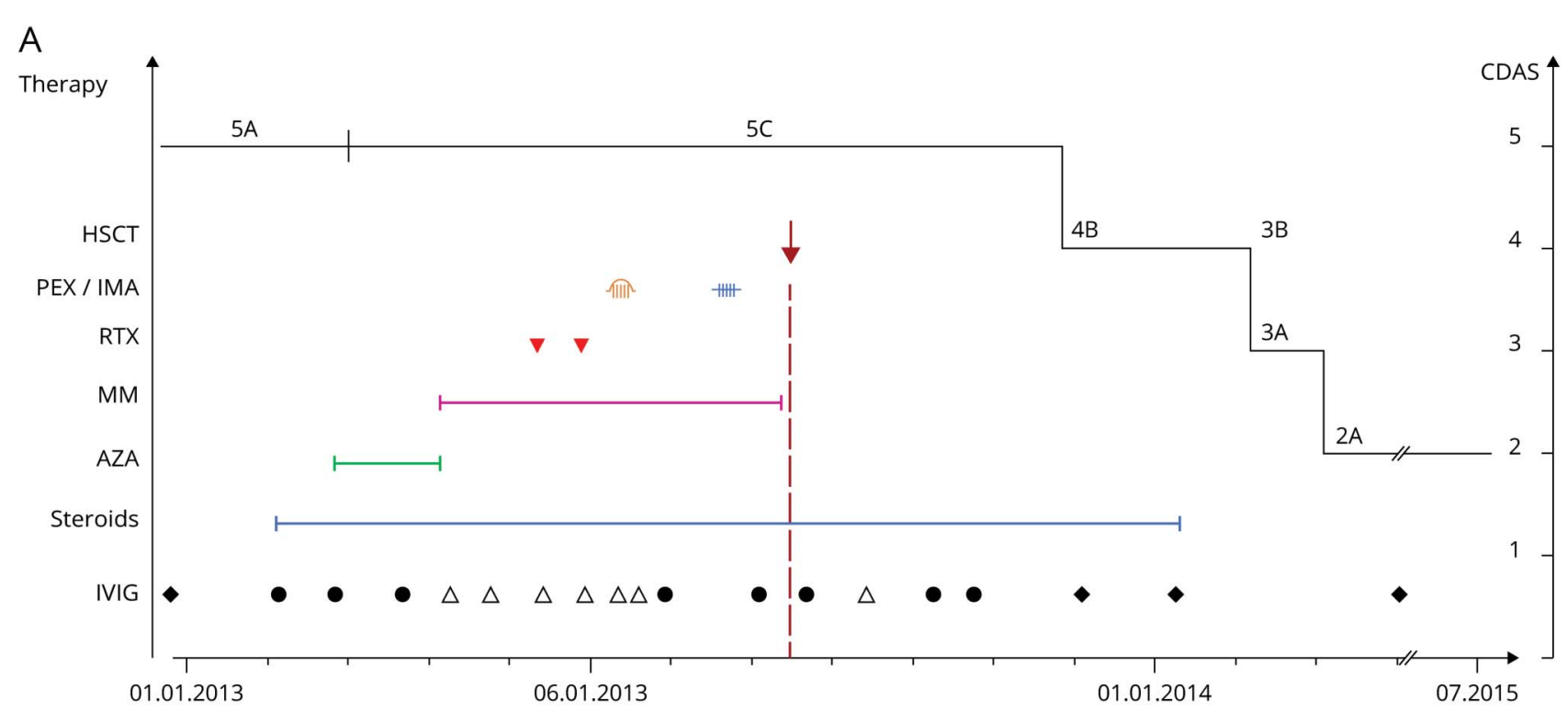

$\mathrm{B}$

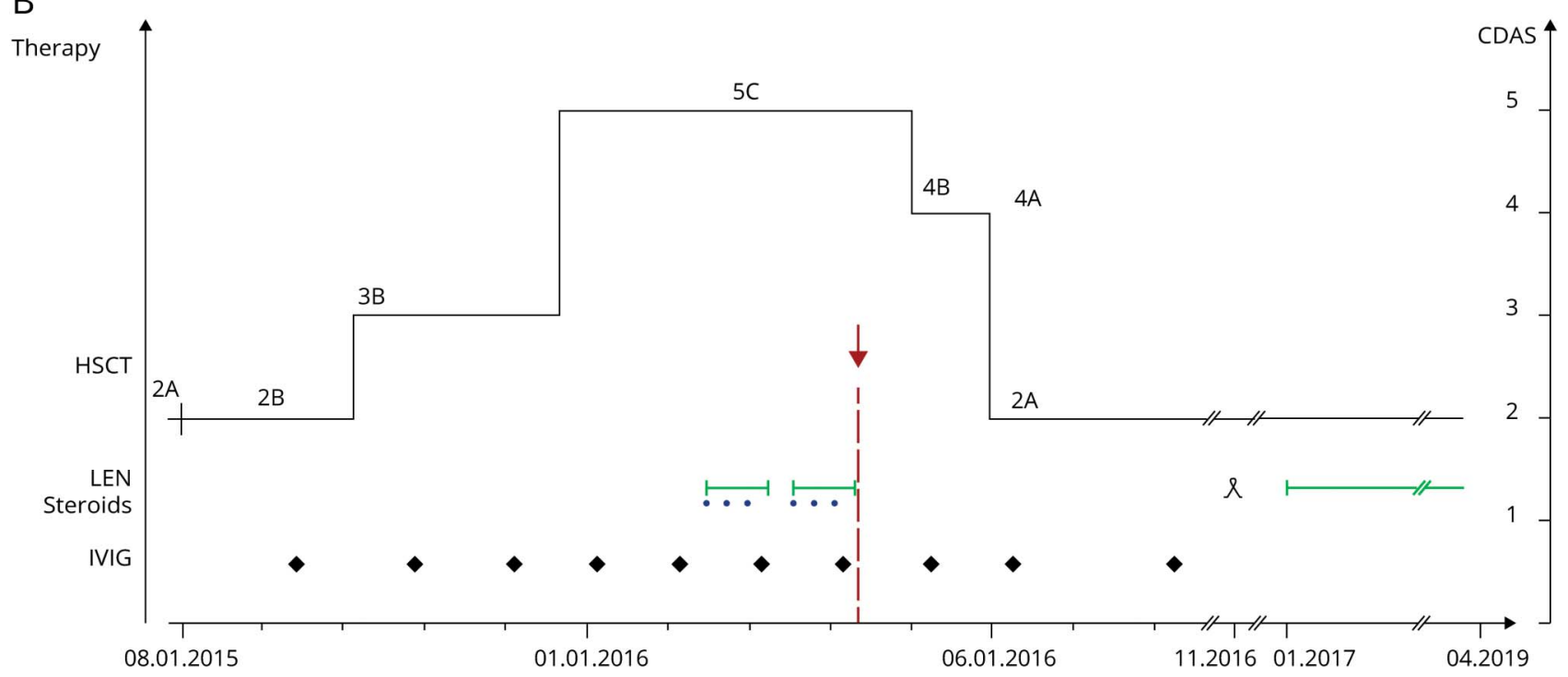

(A) Timeline and relationship between neurologic symptoms according to CDAS and treatment strategies at presentation. CDAS score 5 represent unstable active disease with abnormal examination and progressive course ( $5 \mathrm{~A}$ treatment $<3$ months, $5 \mathrm{C}$ on treatment). Score 4 : improvement $>3$ months, $<1$ year ( $4 \mathrm{~A}$ with normal examination, 4B with abnormal examination). Score 3: stable active disease $>1$ year (3A with normal examination, 3B with abnormal examination). Score 2: remission $<5$ years, off treatment ( $2 \mathrm{~A}$ with normal examination, $2 \mathrm{~B}$ with abnormal examination). Score 1 cure $>5$ years, off treatment. (B) Timeline and relationship between treatment and neurologic symptoms according to CDAS at relapse. IVIG, high-dose immunoglobulin: symbol represent IVIG treatment cycles: $0.4 \mathrm{~g} / \mathrm{kg}$ (35 g), $\Delta 1.0 \mathrm{~g} / \mathrm{kg}(85 \mathrm{~g}), \quad 2 \mathrm{~g} / \mathrm{kg}(160 \mathrm{~g}) ;$ blue line: steroids; green line: AZA; purple line: MM; red triangle ( $\mathbf{\nabla})$ : RTX; orange: PEX; blue: IMA; green line fine: LEN; red arrow $(\downarrow)$ : autologous HSCT; $\square$ preventive hematopoietic stem cell mobilization and collection. AZA = azathioprine; CDAS = CIDP disease activity status; HSCT = hematopoietic stem cell transplantation; IMA = immunoabsorption; IVIG = IV immunoglobulin; LEN = lenalidomide; MM = mycophenolate mofetil; PEX = plasmapheresis; $\mathrm{RTX}=$ rituximab.

with melphalan, followed by autologous HSCT together with continued IV immunoglobulin (IVIG) therapy were administered as salvage therapy (figure 1).

Conditioning treatment was melphalan $\left(200 \mathrm{mg} / \mathrm{m}^{2} \mathrm{IV}\right)$. Stem cell mobilization for autologous HSCTs was performed by vinorelbine $\left(35 \mathrm{mg} / \mathrm{m}^{2} \mathrm{IV}\right)$ and G-CSF $(10 \mu \mathrm{g} / \mathrm{kg}$ body weight). A total of $3.2 \times 10^{6} \mathrm{CD}^{+} 4^{+}$cells $/ \mathrm{kg}$ b.w. were transfused at the day 0 of autologous HSCT. The patient fully recovered and resumed his professional activities (figure 1). The free-serum light chain ratio and the previously suppressed lambda light chains normalized (table e-2, links.lww. com/NXI/A314).

Two years after HSCT, the patient presented with a clinical relapse. Bone marrow analysis was again compatible with IgG kappa MGUS with 4\% kappa light-chain restricted plasma cells (table e-2, links.lww.com/NXI/A314). Chromosome 
banding analysis and FISH at that time identified monosomy $13 q 14.3$ and $t(11 ; 14)$. Despite IVIG, the neurologic symptoms worsened, and a second autologous HSCT was performed after conditioning with melphalan $\left(200 \mathrm{mg} / \mathrm{m}^{2} \mathrm{IV}\right)$ preceded by 2 cycles of lenalidomide $(25 \mathrm{mg} / \mathrm{d}$ on a 21 -days cycle) and steroids. Neurologic symptoms completely resolved within weeks (figure 1). Continuous maintenance therapy with lenalidomide $10 \mathrm{mg} / \mathrm{d}$ on 21-days cycles was started. Three years after the second HSCT, the patient was still asymptomatic.

\section{Discussion}

We describe a strong and timely correlation between 2 HSCTs and the resolution of the CIDP-related neurologic symptoms. Particularly at relapse, when the second HSCT was performed immediately after clinical aggravation, clinical improvement was prompt. Neurologic improvement was closely correlated with the rebalance of the serum free light chains after both HSCTs. The mechanism of HSCT-induced CIDP remission is not yet defined. Based on the normalization of the serum-free light chains kappa and lambda regarding absolute values and ratio after both HSCTs, we speculate that it may be attributed to the regression of the immune-mediated mechanisms related to the shrinking MGUS clone.

Our report confirms the positive impact of melphalan conditioning preceding autologous HSCT in patients with MGUS-associated neurologic disorders.

The favorable outcome of our approach at relapsing emphasizes to further explore adding lenalidomide for induction and post-transplant maintenance therapy in case of CIDP and concurrent IgG kappa MGUS. Our report may as well suggest to investigate other novel myeloma-specific therapeutic approaches in clinically refractory CIDP with concurrent MGUS, e.g., the anti-CD38 antibody daratumumab and venetoclax, a selective, orally bioavailable B-cell lymphoma 2 inhibitor that induces cell death in multiple myeloma cells, particularly in those harboring $t(11 ; 14)$, that express high levels of B-cell lymphoma 2 relative to B-cell lymphoma-extra large and myeloid leukemia cell 1.

\section{Acknowledgment}

Mrs. Daniela Rusca-Vitulano, Clinica Luganese Moncucco, assisted with figure preparation. Liliane Petrini, Ospedale Regionale di Lugano Civico e Italiano, performed technical editing and manuscript submission.

\section{Study funding}

This study did not receive funding.

\section{Disclosure}

G. Colucci, T. Pabst, U. Bacher, C. Maggioli, and C. Zecca report no disclosures. The Department of Neurology, Regional Hospital Lugano (EOC), Lugano, Switzerland receives financial support from AbbVie, Almirall, Biogen Idec, Celgene, Lilly, Merck, Novartis, Sanofi, and Teva Pharma. C. Gobbi reports no disclosures. The Department of Neurology, Regional Hospital Lugano (EOC), Lugano, Switzerland, receives financial support from AbbVie, Almirall, Biogen Idec, Celgene, Lilly, Merck, Novartis, Sanofi, and Teva Pharma. Go to Neurology.org/NN for full disclosures.

\section{Publication history}

Received by Neurology: Neuroimmunology \& Neuroinflammation April 6, 2020. Accepted in final form August 19, 2020.

Appendix Authors

\begin{tabular}{|c|c|c|}
\hline Name & Location & Contribution \\
\hline $\begin{array}{l}\text { Giuseppe } \\
\text { Colucci, } \\
\text { MD }\end{array}$ & $\begin{array}{l}\text { Clinica Luganese } \\
\text { Moncucco, Lugano, } \\
\text { Switzerland }\end{array}$ & $\begin{array}{l}\text { Conceptualization of the study, } \\
\text { interpretation of the data, } \\
\text { drafting the manuscript, and } \\
\text { revising the manuscript for } \\
\text { intellectual } \\
\text { content }\end{array}$ \\
\hline $\begin{array}{l}\text { Thomas } \\
\text { Pabst, } \\
\text { MD }\end{array}$ & $\begin{array}{l}\text { University Hospital and } \\
\text { University of Bern, } \\
\text { Switzerland }\end{array}$ & $\begin{array}{l}\text { Interpretation of the data and } \\
\text { revising the manuscript for } \\
\text { intellectual content }\end{array}$ \\
\hline $\begin{array}{l}\text { Ulrike } \\
\text { Bacher, } \\
\text { MD }\end{array}$ & $\begin{array}{l}\text { University Hospital and } \\
\text { University of Bern, } \\
\text { Switzerland }\end{array}$ & $\begin{array}{l}\text { Interpretation of the data and } \\
\text { revising the manuscript for } \\
\text { intellectual content }\end{array}$ \\
\hline $\begin{array}{l}\text { Caterina } \\
\text { Maggioli, } \\
\text { MD }\end{array}$ & $\begin{array}{l}\text { Clinica Luganese } \\
\text { Moncucco, Lugano, } \\
\text { Switzerland }\end{array}$ & $\begin{array}{l}\text { Conceptualization of the study, } \\
\text { interpretation of the data, } \\
\text { drafting the manuscript, and } \\
\text { revising the manuscript for } \\
\text { intellectual } \\
\text { content }\end{array}$ \\
\hline $\begin{array}{l}\text { Chiara } \\
\text { Zecca, } \\
\text { MD }\end{array}$ & $\begin{array}{l}\text { Ospedale Regionale di } \\
\text { Lugano Civico e Italiano, } \\
\text { Switzerland }\end{array}$ & $\begin{array}{l}\text { Interpretation of the data and } \\
\text { revising the manuscript for } \\
\text { intellectual content }\end{array}$ \\
\hline $\begin{array}{l}\text { Claudio } \\
\text { Gobbi, } \\
\text { MD }\end{array}$ & $\begin{array}{l}\text { Ospedale Regionale di } \\
\text { Lugano Civico e Italiano, } \\
\text { Switzerland }\end{array}$ & $\begin{array}{l}\text { Conceptualization of the study, } \\
\text { interpretation of the data, and } \\
\text { revising the manuscript for } \\
\text { intellectual } \\
\text { content }\end{array}$ \\
\hline
\end{tabular}

\section{References}

1. Rajabally YA, Attarian S. Chronic inflammatory demyelinating polyneuropathy and malignancy: a systematic review. Muscle Nerve 2018;57:875-883.

2. Alkhawajah NM, Dunnigan SK, Bril V. Comparison of monoclonal gammopathy of undetermined significance-associated neuropathy and chronic inflammatory demyelinating polyneuropathy patients. J Neurol 2014;261:1485-1491.

3. Joint Task Force of the EFNS and the PNS. European Federation of Neurological Societies/Peripheral Nerve Society guideline on management of paraproteinemic demyelinating neuropathies. Report of a joint task force of the European Federation of Neurological Societies and the Peripheral Nerve Society-first revision. J Peripher Nerv Syst 2010;15:185-195.

4. Dalakas MC; Medscape. Advances in the diagnosis, pathogenesis and treatment of CIDP. Nat Rev Neurol 2011;7:507-517.

5. Puyade M, Labeyrie C, Badoglio M, et al. Indication of autologous stem cell transplantation in chronic inflammatory demyelinating polyneuropathy: guidelines from the Francophone Society of Bone Marrow Transplantation and Cellular Therapy (SFGM-TC) [in French]. Bull Cancer 2020;107:S104-S113.

6. Lee YC, Came N, Schwarer A, Day B. Autologous peripheral blood stem cell transplantation for peripheral neuropathy secondary to monoclonal gammopathy of unknown significance. Bone Marrow Transpl 2002;30:53-56.

7. Van den Bergh PY, Hadden RD, Bouche P, et al. European Federation of Neurological Societies/Peripheral Nerve Society guideline on management of chronic inflammatory demyelinating polyradiculoneuropathy: report of a joint task force of the European Federation of Neurological Societies and the Peripheral Nerve Societyfirst revision. Eur J Neurol 2010;17:356-363. 


\section{Neurology \\ Neuroimmunology \& Neuroinflammation}

A case of CIDP concurrent with MGUS IgG kappa responsive to autologous stem cell transplantation

Giuseppe Colucci, Thomas Pabst, Ulrike Bacher, et al.

Neurol Neuroimmunol Neuroinflamm 2020;7;

DOI 10.1212/NXI.0000000000000888

This information is current as of September 15, 2020

Neurol Neuroimmunol Neuroinflamm is an official journal of the American Academy of Neurology.

Published since April 2014, it is an open-access, online-only, continuous publication journal. Copyright

Copyright $\odot 2020$ The Author(s). Published by Wolters Kluwer Health, Inc. on behalf of the American

Academy of Neurology.. All rights reserved. Online ISSN: 2332-7812.

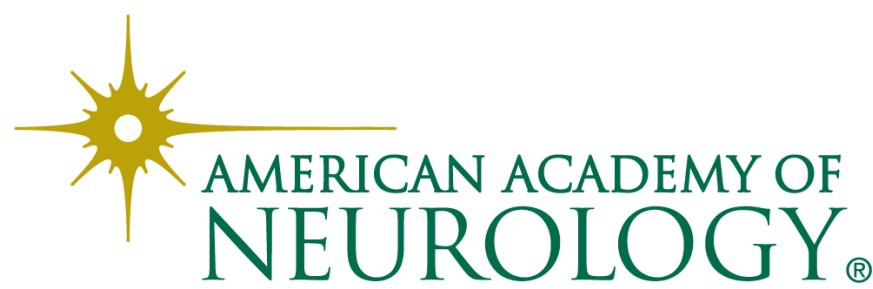




\section{Updated Information \& Services}

References

Citations

Subspecialty Collections

Errata

Permissions \& Licensing

Reprints including high resolution figures, can be found at: http://nn.neurology.org/content/7/6/e888.full.html

This article cites 7 articles, 0 of which you can access for free at: http://nn.neurology.org/content/7/6/e888.full.html\#\#ref-list-1

This article has been cited by 1 HighWire-hosted articles: http://nn.neurology.org/content/7/6/e888.full.html\#\#otherarticles

This article, along with others on similar topics, appears in the following collection(s):

Chronic inflammatory demyelinating polyneuropathy

http://nn.neurology.org//cgi/collection/chronic_inflammatory_demyeli nating_polyneuropathy

An erratum has been published regarding this article. Please see next page or:

/content/8/3/e995.full.pdf

Information about reproducing this article in parts (figures,tables) or in its entirety can be found online at:

http://nn.neurology.org/misc/about.xhtml\#permissions

Information about ordering reprints can be found online: http://nn.neurology.org/misc/addir.xhtml\#reprintsus

Neurol Neuroimmunol Neuroinflamm is an official journal of the American Academy of Neurology.

Published since April 2014, it is an open-access, online-only, continuous publication journal. Copyright

Copyright $\odot 2020$ The Author(s). Published by Wolters Kluwer Health, Inc. on behalf of the American Academy of Neurology.. All rights reserved. Online ISSN: 2332-7812.

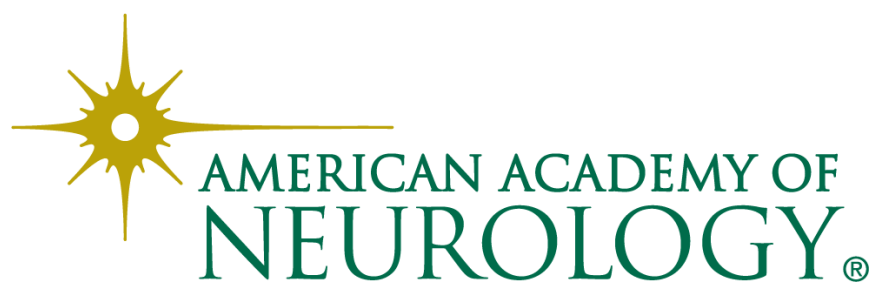




\section{A Case of CIDP Concurrent With MGUS IgG Kappa Responsive to Autologous Stem Cell Transplantation}

Neurol Neuroimmunol Neuroinflamm 2021;8:e995. doi:10.1212/NXI.0000000000000995

In the Clinical/Scientific Note "A case of CIDP concurrent with MGUS IgG kappa responsive to autologous stem cell transplantation" by Colucci et al, ${ }^{1}$ the legend of figure 1 should include the $\boldsymbol{\ell}$ symbol before "preventive hematopoietic stem cell mobilization and collection." The publisher regrets the error.

Further, the final sentence of the Discussion section should read, "Our report may as well suggest investigating other novel myeloma-specific therapeutic approaches in clinically refractory CIDP with concurrent MGUS, e.g., the anti-CD38 antibody daratumumab and venetoclax, a selective, orally bioavailable B-cell lymphoma 2 (BCL-2) inhibitor that induces cell death in multiple myeloma cells, particularly in those harboring $t(11 ; 14)$, that express high levels of BCL-2 relative to BCL-extra large (BCL-XL) and myeloid cell leukemia 1 (MCL-1).” The authors regret the error.

\section{Reference}

1. Colucci G, Pabst T, Bacher U, et al. A case of CIDP concurrent with MGUS IgG kappa responsive to autologous stem cell transplantation. Neurol Neuroimmunol Neuroinflamm 2020;7:e888. doi: 10.1212/NXI.0000000000000888. 